\title{
SEISMIC CHARACTERIZATION OF INTERNAL SALT CYCLES: A CASE STUDY IN THE SANTOS BASIN, BRAZIL
}

\author{
Rodrigo Leandro B. Pontes (iD) ${ }_{1,2 *}$, Alexandre Rodrigo Maul (D) 1,2 and Cleverson Guizan Silva ${ }_{2}$
}

\begin{abstract}
The exploration of pre-salt reservoirs in the Santos Basin, Brazilian Offshore, requires innovative approaches to improve the quality of reservoir seismic images below large salt bodies, helping to enhance the depth predictions and to improve security for drilling operations. Salt is a general term for evaporites that may present an enormous complexity. Outcrop and experimental data show that evaporites precipitate in a controlled and defined order, respecting increasing brine salinity. When analyzing the Ariri Formation (salt section) in the Santos Basin we recognize several evaporation salt cycles, indicating climatic and tectonic controls. In this work, we identify the salt cycles in wells and integrate those with the seismic data as low-frequency events to create detailed velocity models. Our results confirm that the incorporation of the salt cycles reduces the average mismatch of depth positioning, consequently, providing reliable volumetric estimations.
\end{abstract}

Keywords: evaporitic section, salt cycles, seismic imaging, seismic inversion, velocity model

RESUMO. A exploração de reservatórios do pré-sal na Bacia de Santos, Offshore Brasileiro, requer abordagens inovadoras para melhorar a qualidade das imagens sísmicas dos reservatórios abaixo de grandes corpos de sal, ajudando a tornar as previsões de profundidade mais precisas e a aumentar a segurança das operações de perfuração. Sal é um termo genérico para evaporitos que podem apresentar uma enorme complexidade. Dados experimentais e de afloramentos mostram que os evaporitos precipitam em ordem bem controlada e definida, respeitando o aumento da salinidade da salmoura. Ao analisar a Formação Ariri (seção de sal) na Bacia de Santos reconhecemos vários ciclos de evaporação do sal, indicando controles climáticos e tectônicos. Neste trabalho, identificamos os ciclos de sal em poços e os integramos aos dados sísmicos como eventos de baixa frequência para criar modelos de velocidade detalhados. Nossos resultados confirmam que a incorporação dos ciclos de sal reduz o erro médio do posicionamento em profundidade e fornece, consequentemente, estimativas volumétricas mais confiáveis.

Palavras-chave: seção evaporítica, ciclos salinos, imageamento sísmico, inversão sísmica, modelo de velocidade 


\section{INTRODUCTION}

The Santos Basin is the largest salt basin in the South Atlantic Ocean and its history begins with the breakup of the Gondwana Supercontinent in the Early Cretaceous (Kukla et al., 2017). During the Aptian, the Santos Basin (SE Brazil) was in a restricted sea isolated from the open oceanic water circulation by the Rio Grande Rise. The restricted conditions stayed for nearly $9 \mathrm{My}$, allowing the formation of brine portions, which creates the perfect conditions for precipitation of evaporites: high evaporation rates, arid climate, and little freshwater inflow. These saline evaporites act as effective and perfect seal for the pre-salt reservoirs in the basin (Carminatti et al., 2008).

Gamboa et al. (2009), analyzing seismic data in the Santos Basin, identify four major units that are formed by a sum of several minor evaporitic cycles in the Ariri Formation. These major units have distinct seismic facies and are preserved in the following order: (1) a thick basal layer composed mostly by halite; (2) a layer with anhydrite on the base followed by halite and bittern salts; (3) another thinner layer of halite; and (4) a thinner layer presenting the same sequence described in (2). Fiduk and Rowan (2012) divide the evaporitic section in three beam layers and three detachment zones. The beams are layers that present high amplitude and continuous trackable reflections, described as 'relatively competent', concentrating most of the anhydrite mineral. The detachment zones, the interval between beams, have low amplitude reflections, poor continuity, and are mostly composed of halite. Jackson et al. (2015) also divide the evaporitic section into four units from base to top, based on seismic patterns: A1, A2, A3 and $A 4$. These authors divide these units based on the percentage of non-halite minerals, such as anhydrite, carnallite, tachyhydrite, related to their density differences. A1 is chaotic-to-weakly stratified and rich in halite; $\mathrm{A} 2$ is a high amplitude and strong reflective unit with less halite than $A 1 ; A 3$ is poorly reflective, with high halite content; and A4 has very strong reflections, less halite and few layers of lowdensity evaporites.
In this study, as a first approach to interpretation, we start using the four-fold sub-division defined by Gamboa et al. (2008) and Jackson et al. (2015), before detailing the minor cycles defined by Freitas (2006). Each of these minor cycles, from base to top, is composed of anhydrite, halite, bittern salts, another layer of halite and another anhydrite closing the loop. It is essential to notice that the bittern salts may not always be present or preserved in the cycles since their precipitation and preservation conditions rarely occur. They tend to happen on central portions of brines, during an extremely arid climate and with little or inexistent freshwater inflow.

The seismic velocity models of salt bodies generally present simplifications, which are frequently treated as almost homogeneous halite bodies. These simplifications affect the seismic migration during the process of image building, the reliability in reservoir depth forecast and well engineering projects, which may cause significant budget losses for the companies in the oil and gas industry.

Recently, several approaches are considering details in the evaporitic section using previous information, such as drilled wells and seismic data, to create more accurate velocity models (Maul et al., 2015; Maul et al., 2019; Maul, 2020; Maul et al., 2021). To complement these studies, it is crucial to understand the salt basin depositional dynamics as well as their structural behavior. After recognizing and correlating the major salt cycles (Gamboa et al., 2008; Fiduk and Rowan, 2012; Jackson et al., 2015, Rodriguez et al., 2018), the small salt cycles (Freitas, 2006) can be inferred using well data and modeled using any seismic inversion strategy or any geostatistical approach (Pontes et al., 2018, 2019; Pontes, 2019; Teixeira et al., 2020; Maul, 2020; Maul et al., 2021).

In this paper, we interpreted and characterized the four primary salt cycles and used the information from wells to obtain the high frequency secondary salt cycles. After that, we performed seismic inversions considering or not the cycles to build the low frequency models. Finally, we used this information to evaluate the relevance of the incorporation of these approaches for seismic activities, especially regarding the uncertainties related to gross rock volume variations. 


\section{SANTOS BASIN: GENERAL GEOLOGY BACKGROUND}

The formation of Santos Basin occurred during the Mesozoic after the Gondwana rifting. The stratigraphy presents three super sequences: Rift, composed mainly by lake and fluvial deposits, post-Rift, the evaporitic phase, which is object of this study, and finally the passive margin sedimentation, characteristic of the Drift phase (Moreira et al., 2007).

In this context, the Santos Basin tectonic and stratigraphic evolutions are closely connected with the South Atlantic opening, in the Lower Cretaceous. Non-marine sediments fill a series of grabens and hemigrabens (Piçarras and Itapema Formations), covered by shallow marine carbonate of Barra Velha Formation (Freitas, 2006). Barremian and Aptian carbonate reservoirs are also present in the Santos Basin, within the pre-salt section represented by lacustrine microbialites and coquinas, with marine influence (Mann and Rigg 2012; Quirk et al. 2012). Usually, a thick salt layer, the Ariri Formation, covers the reservoirs, in some locations thicker than $2,000 \mathrm{~m}$. The reservoirs occur between 5,000 and 6,000 m below the sea level. The evaporite precipitation of Ariri Formation happened between the sag and marine phases during a fast subsidence regime, forming the Aptian South Atlantic Salt Basin (Kukla et al., 2017).

This Aptian South Atlantic Salt Basin was more than 2,000 km long, $400 \mathrm{~km}$ wide in its southern portion and around $100 \mathrm{~km}$ wide northward. The estimated average thickness of the completely evaporitic section was around 2,000 m before halokinesis occurred (Mohriak et al., 2012). Presently, the evaporitic section varies from few hundred to around 3,000 m (Gamboa et al., 2008, Mohriak et al., 2012). Rodriguez et al. (2018) estimate that the entire evaporitic section was deposited in about $530 \mathrm{Ky}$, with a cyclicity of fourth to fifth-order, low-amplitude sea-level changes, which are interpreted as having typical greenhouse characteristics. This dimension and volume of evaporite deposition suggest that Santos Basin deposits falls in the basinward evaporite classification as described by Warren (2006).

\section{EVAPORITES AND THE SALT CYCLES}

Warren (2006) defines evaporites as a group of sedimentary deposits formed largely due to evaporation. Large bodies of evaporites, also known as saline giants, as the ones found in Santos Basin, form in restricted bodies of water under specific climate conditions, especially arid climates and high evaporation rates. The composition and geometry of deposition of the minerals depend on the chemical composition of the water and adjacent rocks, as well as climatic and tectonic conditions (Rodriguez et al., 2018).

Saline evaporites have high solubility and halokinetic properties, that make most of them chemically and physically very mobile, both in the sedimentary environment and particularly during burial and diagenesis. For example, as burial begins and temperature increases, precipitated gypsum dehydrates, and the original mineral converts into anhydrite. These characteristics make the interpretation of ancient evaporites strongly dependent on climatic and tectonic models (Warren, 2016). This same author states that: "larger examples of modern evaporites are dominantly supra-sea level nonmarine lacustrine deposits, while ancient evaporites are subsea level marine fed systems. Yet, the first-order latitudinal distribution of modern and ancient evaporite basins is similar. That is, the dominant world-scale control on evaporite distribution is climatic and largely the result of the presence of Hadley cells". This statement is important to support our main understanding of the whole process of evaporite formation and its intrinsic cyclicity.

According to Warren (2006), there are three different models for basin filling with evaporitic precipitation: deep basin/deep water, deep basin/shallow water, and shallow basin/shallow water. We assume that the Aptian South Atlantic Salt Basin is an example of a deep basin/shallow water setting (Fig. 1). In this setting, shallow water evaporites predominate, deposited as stacked saltern to mudflat cycles in a basin with hydrological level several hundreds of meters below mean sea 
level. The tectonic and eustatic conditions required for the formation of widespread marine evaporites are not recognized in the modern world (Warren, 2006; 2016).

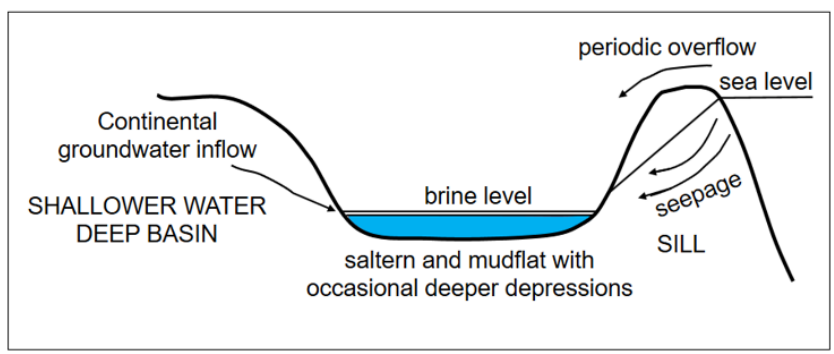

Figure 1 - Most likely setting for basinwide evaporite deposition in Aptian South Atlantic Salt Basin during the Aptian, where the Santos Basin is inserted in the context. (Modified from Warren, 2006).

For the purpose of this research, we define a salt cycle as the full length of a brining upward, i.e., basin desiccation, and a deepening upward, i.e., basin filling (Freitas, 2006; Rodriguez et al., 2018; Pontes et al., 2019; Teixeira et al., 2020). Brining upward occurs when the rate of evaporation is higher than the rate of water influx to the system. As water evaporates, the density and ionic concentration of the brine increases, and when this concentration reaches a critical point, the evaporite precipitation begins (Fig. 2).

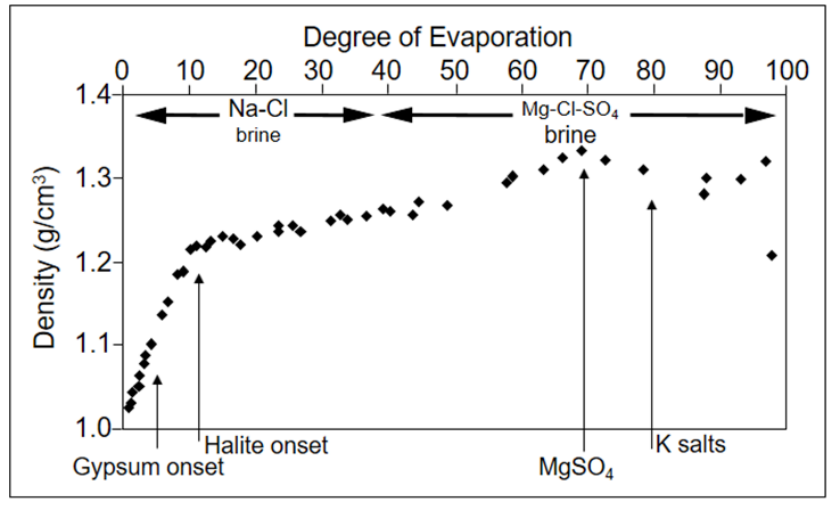

Figure 2 - Evaporation pathway of modern seawater showing how density increases and how the proportion of various ions in solution changes as the brine concentration increases (modified from Warren, 2006).

Usiglio (1849) also demonstrates this behavior of evaporite precipitation in its first known experiment of complete seawater evaporation. As the degree of evaporation increases, evaporites precipitate from the least to the most soluble minerals: carbonates, gypsum, halite and finally the bittern salts. The reference to this evaporation pattern is the "Usiglio Sequence", and this concept is still largely used.

It is logical to assume that when the water inflow into the basin is higher than the evaporation rate, the inverse precipitation order is observed: bittern salts, halite, gypsum and carbonates. This corresponds to the deepening upward cycle (brining downward).

\section{The Importance of Characterization of the Evaporitic Section}

According to Maul et al. (2019), based on the data acquired from about 200 drilled wells, the most common mineral found in the Santos Basin evaporitic section is halite. For this reason, the evaporitic section characteristics, including seismic velocity and density, are frequently represented by halite. However, a closer look to tomographic inversions reveals inconsistencies and velocity anomalies that do not conform to the stratigraphic configuration found in the seismic data.

Until the early 2,000's, the evaporitic section in the Santos Basin was modeled as having homogeneous compressional velocity $-4,500 \mathrm{~m} / \mathrm{s}$ (similar to halite compressional velocity value). This is a valid assumption for PSTM (Pre-Stack Time Migration) algorithms, which cannot handle strong lateral compressional velocity variations (Yilmaz, 2001).

With the increase in processing power and the development of new migration algorithms, PSDM (Pre-Stack Depth Migration) became the industry standard, and the representation of existing lateral variations for velocity inputs is necessary for the creation of more reliable seismic images (Ji et al., 2011).

Huang et al. (2010) consider the presence of layered evaporites in the Santos Basin and publish results for velocity correction using tomographic inversion. Tomography based intrasalt travel times 
yield good results because layered evaporites create strong reflections, ensuring the correct update. Without a proper initial model, even tomographic inversions are not able to correctly represent and update the velocities, due to the complex nature of the environment that may have steep dips and sharp contrasts. Some authors have explored the use of inhomogeneous/heterogeneous evaporitic sections for enhancing migration output (Maul et al., 2015; Gobatto et al., 2016; Fonseca et al., 2017; Fonseca et al., 2018; Maul et al., 2018a; 2018b; Maul et al., 2019; Maul, 2020).

Tarantola (1984) and Zhang and Wang (2009), among other authors, strongly indicate FWI and intrasalt tomography to update salt velocity models. Still, both methods need a good starting velocity model that, at least, fairly represents the local geology (Maul, 2020).

\section{Study Area and Available Data}

The study area is inserted in the pre-salt province of Santos and Campos Basins (Fig. 3). A PSDM volume covering an area of approximately 100 $\mathrm{km}^{2}$ and 8 wells with a basic suite of logs are available (Table 1). To simplify the official names of the wells, we are using capital letters (A to $H$ ) and Table 1 brings the correspondence between the official names Agência Nacional do Petróleo, Gás Natural e Biocombustíveis (ANP) and our nomenclature. ANP provides all data we use in this research.

\section{METHODOLOGY}

The adopted methodology follows the work of Pontes (2019) and consists in identifying the major salt cycles inside the Ariri Formation using well logs, and extrapolating these cycles to the seismic data to create low-frequency models for seismic inversion. The resulting models considered the top and base of salt besides three horizons reflecting the cycle separations. The obtained impedance response was transformed to compressional velocity taking an empirical relation (Maul et al., 2019), allowing the depth positioning of seismic events we are interested in. The top of the Barra Velha Formation reservoir is the well-marker used for comparison among different velocity models: 1) constant salt velocity, 2) salt tomographic inversion, 3) the standard seismic inversion model, described by Maul el al. (2009), and 4) the cycles seismic inversion model developed in the present work. The result analysis considers the mismatch between the well-marker of the top of Barra Velha Formation and the depth positioning for the correspondent seismic event for each velocity model at the well location. The applied methodology involved the following main steps:

a) Interpretation of brining upward/deepening upward salt cycles based on the well logs;

b) 1D seismic signal modeling for each well in order to understand any seismic signature of the salt cycles (majors and minors), evaluating the possibility to track these cycles through the seismic data;

c) Mapping of the interpreted/inferred salt cycles on the seismic data;

d) Use of mapped cycle surfaces as guides to create low-frequency models for seismic inversion;

e) Execution of a seismic inversion that reproduces the stratification observed in the well data using a low-frequency model driven by the interpreted cycles;

f) Transformation of the impedance values to velocity using an empirical relationship

Comparison of the mismatch between a reference surface and its correspondent well marker and GRV (Gross Rock Volume) among the different models. 


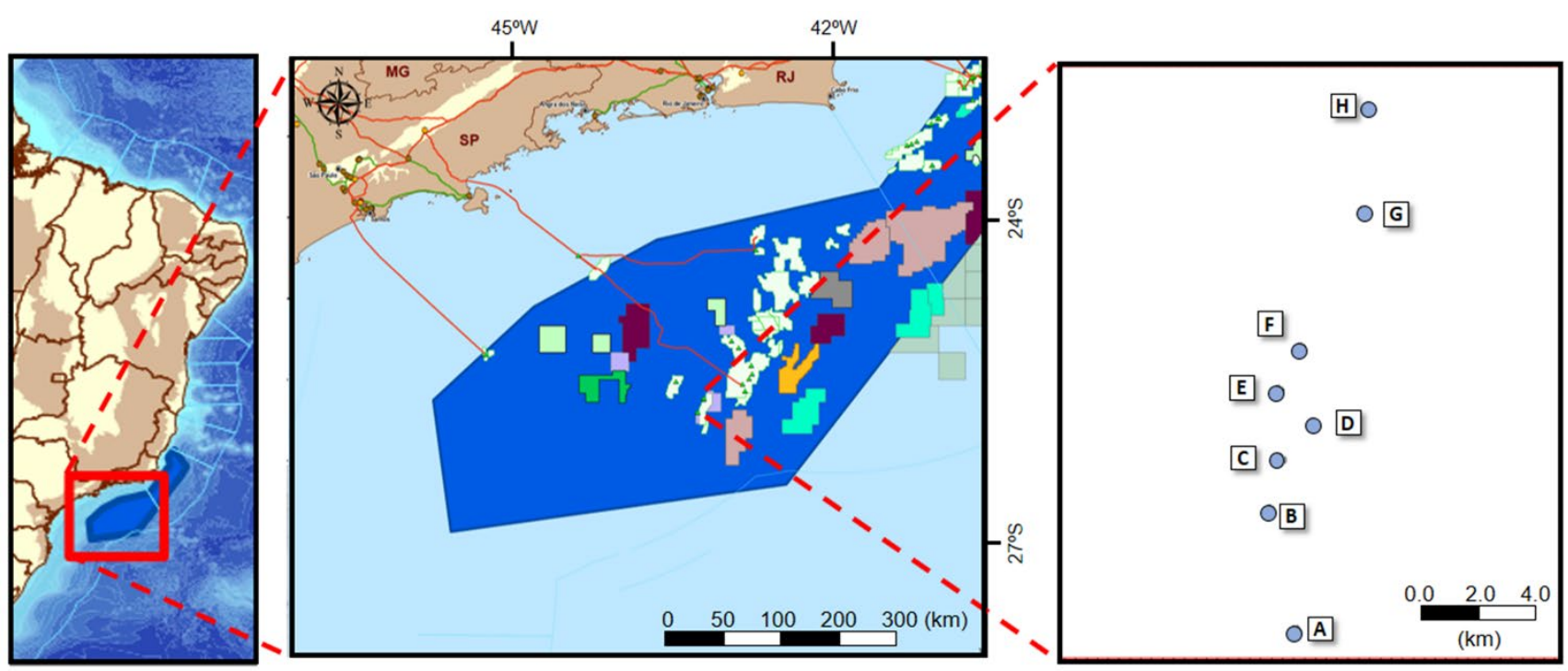

Figure 3 - Location map of the Bauna and Piracaba Fields (BM-S-40), Santos Basin. The blue dashed line outlines the used 3D seismic survey. Wells are represented by letters and points in BM-S-40.

Table 1 - The official names used in this study, after the ANP (National Agency of Petroleum - Brazil) authorization.

\begin{tabular}{|c|c|}
\hline This Study & ANP \\
\hline A & 3-BRSA-923A-SPS \\
\hline B & 7-SPH-1-SPS \\
\hline C & 1-BRSA-594-SPS \\
\hline D & 9-BRSA-1043-SPS \\
\hline E & 7-SPH-5-SPS \\
\hline F & 9-BRSA-928-SPS \\
\hline G & 7-SPH-8-SPS \\
\hline H & 8-SPH-23-SPS \\
\hline
\end{tabular}

\section{RESULTS}

After the integrated analysis of the seismic and well data, we recognized the same four major units previously described by Gamboa et al. (2008) and Jackson et al. (2015). In Figure 4 we show the extracted seismic data along well $A$, and the correlation with the synthetic data calculated from the reflectivity coefficient log, derived from acoustic impedance, convolved with a Ricker wavelet of 25 $\mathrm{Hz}$. The units are correspondent to the major salt cycles, determined from the analysis of well geophysical logs and lithology. Each major cycle corresponds to a brining-upward (precipitation series of anhydrite, halite and bittern salts) followed by a deepening-upward (precipitation series of bittern salts, halite and anhydrite) succession. Each cycle limit correlates with prominent seismic reflections, delimiting different seismic facies correspondent to the units described in literature and summarized in Table 2.

Figure 5 is a composite section along the wells showing the interpretation with the recognized units, integrating seismic and well data:

Unit 1: It presents a mostly transparent, chaotic seismic facies with locally stronger reflections and large thickness variations. This unit has a high halite proportion ( 92\%) as confirmed by the wells. The lower boundary is a strong positive reflection (increasing impedance) related to the basal anhydrite/carbonate lithological contact; the upper boundary is a positive reflection related to a relatively thick anhydrite layer.

Unit 2: It is a highly stratified unit, with strong reflections, less halite $(\sim 83 \%)$ and more anhydrite/halite/bittern salt intercalation. The upper boundary, similar to the previous unit, is a positive reflection related to a relatively thick anhydrite layer. 


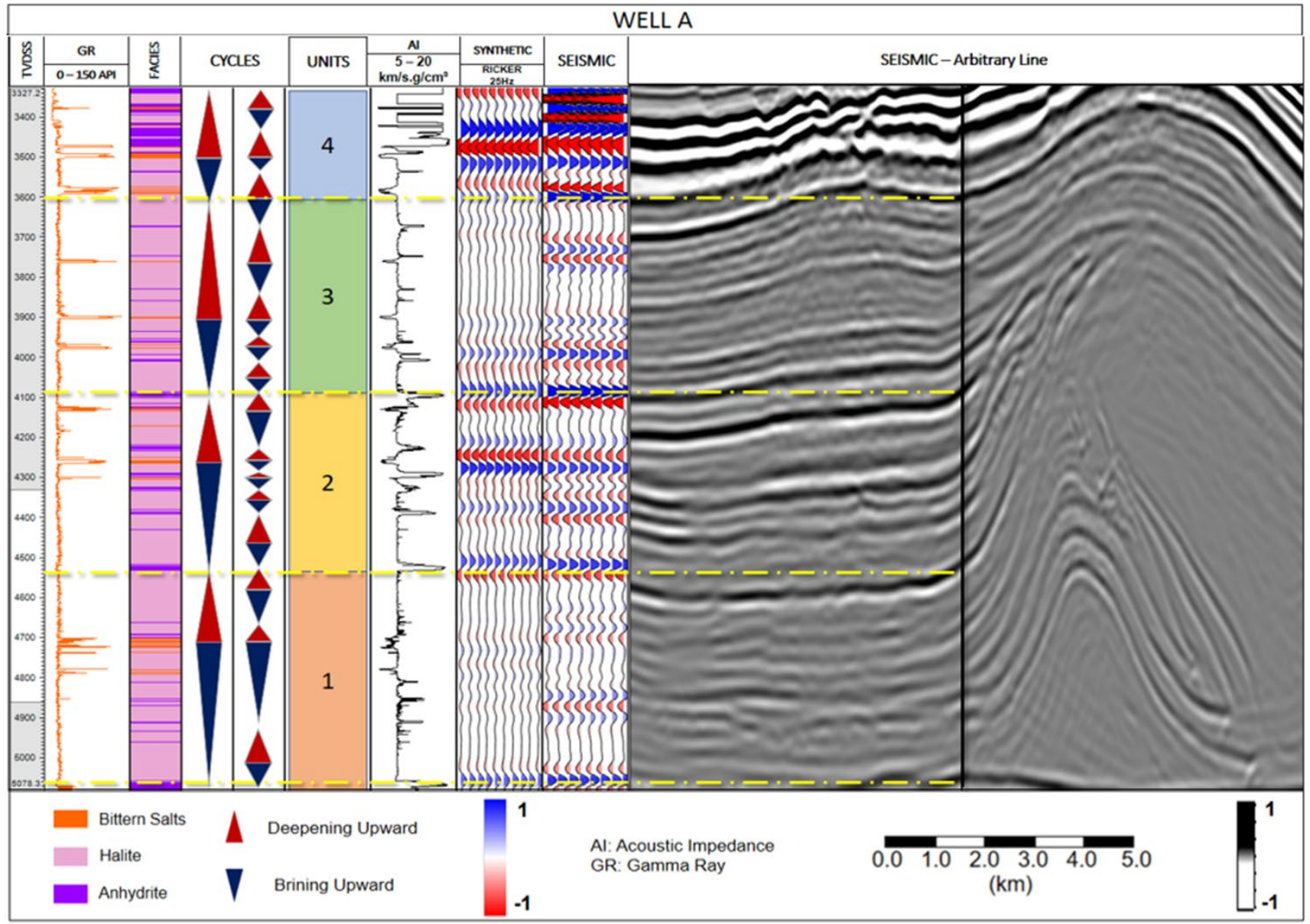

Figure 4 - Well section showing the extracted seismic data along the wells and the correlation with synthetic data calculated from the reflectivity coefficient log, derived from acoustic impedance, convolved with a Ricker wavelet of $25 \mathrm{~Hz}$. From this section, it is possible to observe that there is a change in the reflection characteristics of the units as described in literature (e.g. Jackson et al., 2015). The expanded seismic section on the right shows a closer look to the cycle stratifications and structural complexity.

Table 1 - The official names used in this study, after the ANP (National Agency of Petroleum - Brazil) authorization.

\begin{tabular}{|c|c|c|c|}
\hline This Study & Gamboa et al. (2008) & Fiduk and Rowan (2012) & Jackson et al. (2015) \\
\hline Unit 4 & Thinner Interbedded unit & B1 & A4 \\
\hline Unit 3 & Thinner Halite-rich unit & D1 & A3 \\
\hline Unit 2 & Interbedded unit & B2 & A2 \\
\hline \multirow{2}{*}{ Unit 1 } & Halite-rich unit & D2 & A1 \\
\cline { 2 - 3 } & & B3 & \\
\hline
\end{tabular}



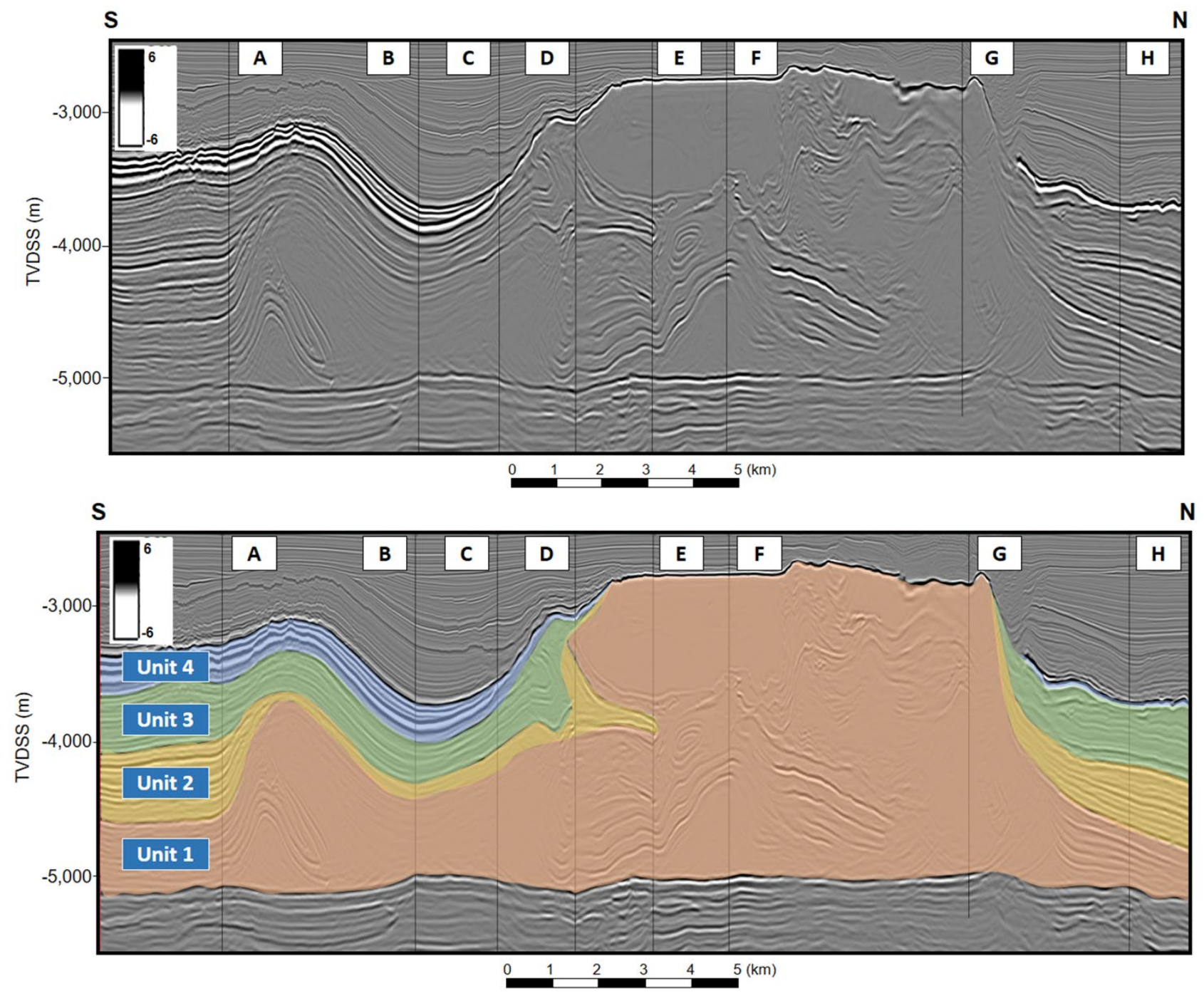

Figure 5 - Composite seismic section along the wells. Upper figure: seismic section in depth. Lower figure: Interpreted units used for this study. For section spatial location, see Figure 3.

Unit 3: It shares the same characteristics of Unit 1 , although less chaotic, presenting more transparent seismic facies, with a few continuous reflections. As Unit 1, the halite proportion is around $92 \%$. Unit 3 is thinner than Unit 1 and does not present dramatic thickness variations; the upper boundary is a positive reflection.

Unit 4: It has less halite than the other units ( $43 \%)$ and a high proportion of anhydrite (47\%) and bittern salts $(10 \%)$. Unit 4 has the strongest reflections observed on the evaporitic section, and it is highly stratified and the thinnest unit. The upper boundary is a strong positive reflection associated with the top of the evaporitic section, which is an anhydrite layer. The mineral percentage occurrences of each mineral are in accordance with previous works (Amaral et al., 2015; Maul et al., 2019; Maul, 2020).

After performing the inversion studies and having the acoustic impedance deliveries, we converted this property (Ip - P impedance) to P-velocity (compressional velocity) that can be used for several seismic processes. Here, we decided to use the same empirical equation used in Maul et al. (2019) and illustrated in Figure 6 to convert the Ip into Vp. The authors grouped the salt mineral established by Maul et al. (2018c): LSV (Low Velocity Salts), which is a family of salts that has the compressional 


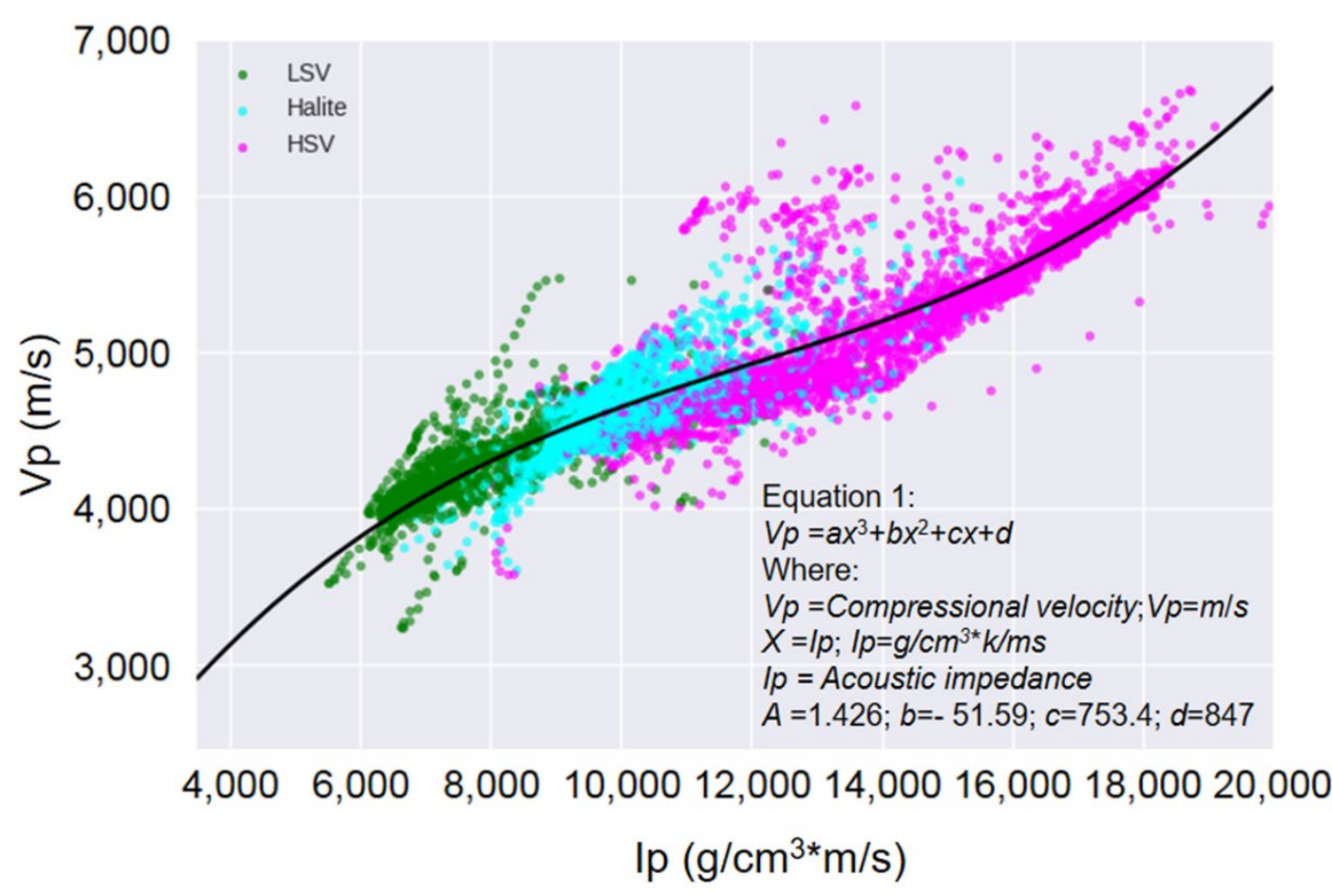

Figure 6 - Vp x IP for different salt groups based on their P-wave velocities. The black line is the polynomial regression that generates the Equation 1, and we used this equation to convert impedance values to velocity values. Adapted from Maul et al. (2019).

velocities lower than halite, and is mainly composed by carnallite, tachyhydrite and sylvite. The HSV (High Velocity Salts) are salts presenting compressional velocities higher than halite, such as anhydrite and gypsum. The halite is the background mineral once it represents about $80 \%$ of occurrence in most of the analyzed studies.

One of the most straightforward ways to assess the impact of a velocity model in a hydrocarbon reservoir is by the time $x$ depth conversion analysis. Therefore, in this work we built four different scenarios to convert the seismic surface relative to the base of salt (top of reservoir) from time to depth. Figure 7 presents the velocity models using the same composite section presented in Figure 5.

Using the velocities from the four different models, we generated the depth positioning of our reference level. In this case, we assume that the base of salt corresponds to the top of the presalt reservoir (Fig. 8).
We assume that the mismatch between the well marker and each one of the depth surfaces is a good indication of the adequacy of the velocity models for depth forecasting purposes (Fig. 8). Figure 9 presents the calculated modulus differences for the depth surfaces using the four salt velocity models in comparison to each well marker depth. The modulus values were chosen to represent the real magnitudes of the mismatch, since positive and negative values may cancel each other (Maul et al., 2021).

\section{DISCUSSION}

In this small portion of the Santos Basin where we conducted this study, there are many locations with evaporitic stratifications. They appear as undisturbed to highly folded, when looking at the seismic data. Even though, the stratifications are showing clear signs of movement, and the seismic facies are easily distinguishable among each other, allowing their interpretation. 

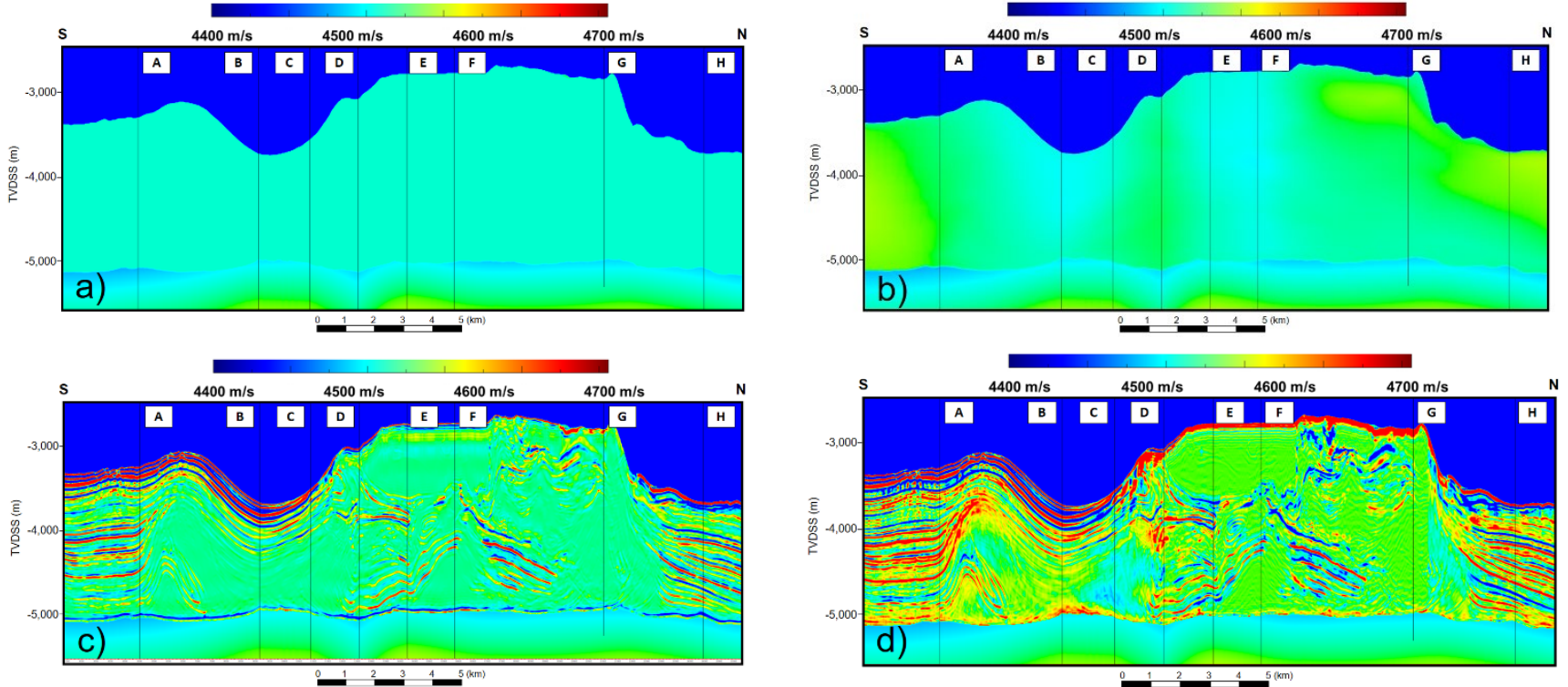

Figure 7 - Velocity model comparison. Capital letters A to $\mathrm{H}$ refer to the wells used in this study. a) Constant Velocity Model. This model represents the evaporitic section as a homogeneous salt body, with constant properties and salt velocity of 4,550 m/s; b) Tomographic Model following the standard seismic processing workflow; c) Standard Seismic Inversion Model using the methodology described in Maul et al. (2009) having the top and base of salt as boundaries for the low frequency model. d) Salt Cycles Seismic Inversion Model. This new inversion considers, besides the top and base of salt, three other internal salt horizons, attempting to represent the cycle separation, to build the low frequency model for the model-based seismic inversion. The velocity conversion from the Ip (models "c" and "d") uses the same equation presented in Figure 6, based on Maul et al. (2019).

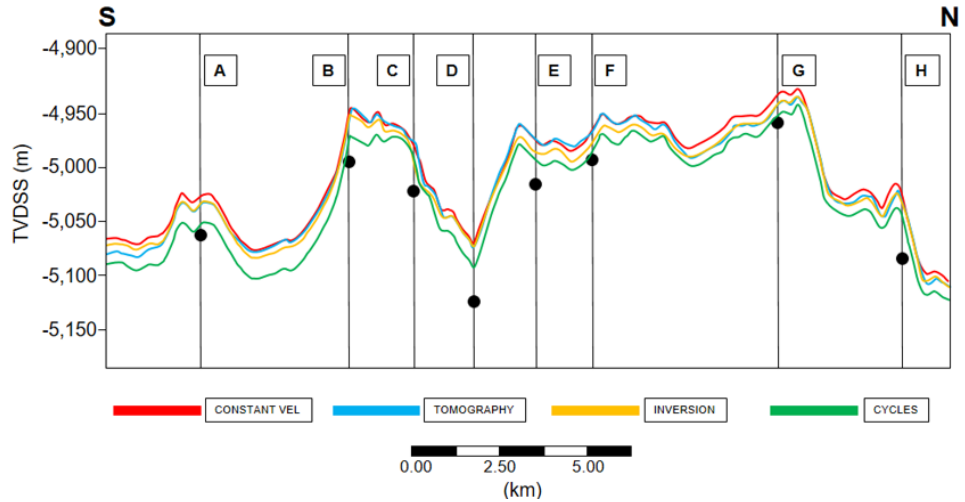

Figure 8 - Section crossing the base of salt surfaces considering the different velocity models. The well markers of the base of salt in each well are the black circles. The vertical scale is magnified by 30 times to emphasize the differences.

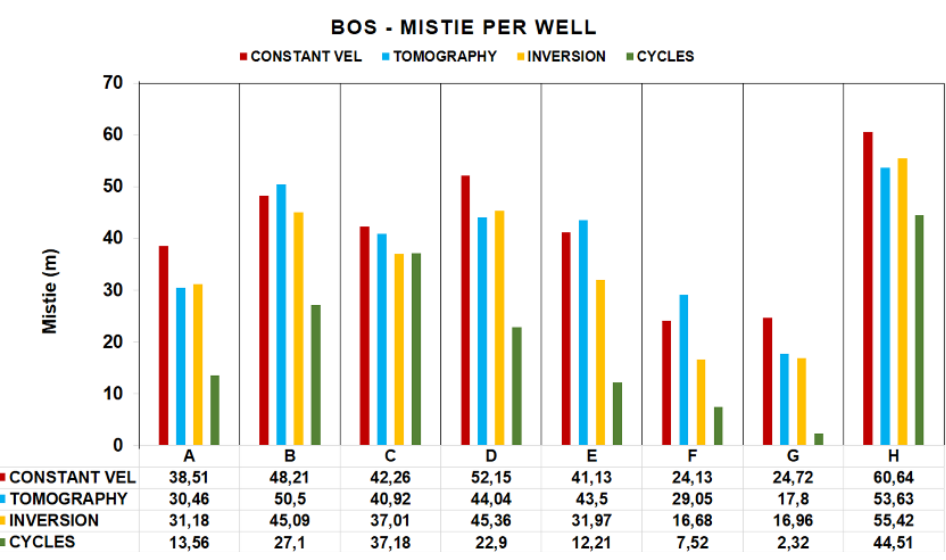

Figure 9 - Modulus values of the mismatch (in meters) between well marker per well and the base of salt (BOS) surfaces for each velocity models. 
Rodriguez et al. (2018) suggest that the compositional differences among units (A1-A4) occur due to changes in salinity, possibly driven by variations in the frequency of marine incursions (deepening upward) and near-desiccation (brining upward) episodes. The authors establish the unit boundaries observing high seismic amplitude contrasts in association with well information. These units were equally recognized in the present study (Units 1 to 4) in well and seismic data corresponding to anhydrite layers thick enough to be solved by the seismic method, appearing as a strong positive seismic reflector (Figs. 4 and 5).

However, the units do not always correspond to the same stage of the interpreted low-frequency cycles. We interpret Unit 1/Unit 2 and Unit 2/Unit 3 boundaries as the end of a deepening upward and the beginning of a brining upward cycle, registered as thick anhydrite layers (Fig. 4). Unit 3/Unit 4 boundary corresponds to a thick carnallite layer, which we interpret as part of a brining upward cycle, corresponding to a strong negative seismic reflector (Fig. 4).This separation is in accordance with Teixeira et al. (2020) and Maul et al. (2021).

The velocity models we created have increasing complexity, such as presented by Maul et al. (2021). The high-frequency cycles illustrated in Figure 4, especially those inside Unit 2 and Unit 3, were considered when building the Salt Cycles Seismic Inversion Model. This assumption provides a more adequate geological velocity model (Fig. 7) when looking at Figure 5 in comparison with the models presented in Figure 7. The average modulus mismatch progressively reduces with the adoption of geologically complex models, as we show on Table 3.

Table 3 - The official names used in this study, after the ANP (National Agency of Petroleum - Brazil) authorization.

\begin{tabular}{|c|c|}
\hline MODEL & AVG. MISMATCH $(\mathbf{m})$ \\
\hline Constant Velocity Model & 37.51 \\
\hline Tomographic Model & 35.90 \\
\hline $\begin{array}{c}\text { Standard Seismic } \\
\text { Inversion Model }\end{array}$ & 31.47 \\
\hline $\begin{array}{c}\text { Salt Cycles Seismic } \\
\text { Inversion Model }\end{array}$ & 22.91 \\
\hline
\end{tabular}

Once the Salt Cycles Seismic Inversion Model provides the minimum modulus average mismatch, we assume this as the appropriate model to consider as a reference for comparison. An important information obtained from the depth variability analysis is the calculation of GRV - Gross Rock Volume. In this study, GRV means the volume of rocks that are above a reference level such as a hypothetical hydrocarbon/water contact. Table 4 shows a GRV calculation with a hypothetical hydrocarbon/water contact at -5,357 m TVDSS.

Table 4 - Gross Rock Volumes calculated using a hypothetical hydrocarbon/water contact at $-5,357 \mathrm{~m}$.

\begin{tabular}{|c|c|}
\hline MODEL & GRV $\left(\times \mathbf{1 0}^{\mathbf{1 0}} \mathbf{m}^{\mathbf{3}}\right)$ \\
\hline Constant Velocity Model & 6.72 \\
\hline Tomographic Model & 6.53 \\
\hline $\begin{array}{c}\text { Standard Seismic } \\
\text { Inversion Model }\end{array}$ & 6.49 \\
\hline $\begin{array}{c}\text { Salt Cycles Seismic } \\
\text { Inversion Model }\end{array}$ & 6.15 \\
\hline
\end{tabular}

The GRV reduction from Constant Velocity Model to Salt Cycles Model is approximately $8 \%$. Comparing the industry standard Tomography Model with the Cycles Model, we have a reduction of about $6 \%$. Finally, when we compare the Inversion Model, we observe a reduction of $5 \%$. Maul et al. (2021), applying the same methodology for a larger area, which includes ours in Santos Basin, show a variation of about $14 \%$ among the models. In another study, Meneguim et al. (2015) observe 3\% GRV variation between two models: (i) inversion tomographic salt model and (ii) salt standard model-based seismic inversion. These differences emphasize the need to consider different velocity scenarios for depth positioning of target surfaces, especially in complex areas, such as those below salt sections.

We also evaluated the GRV spatial variation between our reference model and the others. The difference maps (Fig. 10) show that the major observed GRV differences are located mainly in the 
Diff: Cycles Inversion - Cte Salt Velocity

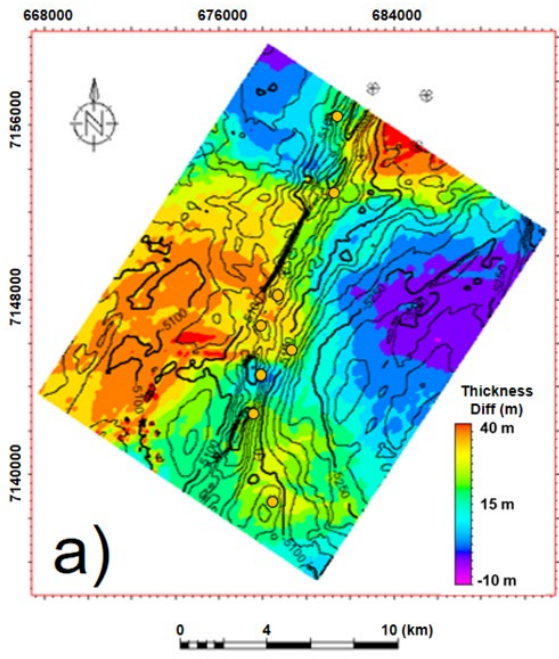

Diff: Cycles Inversion - Tomography

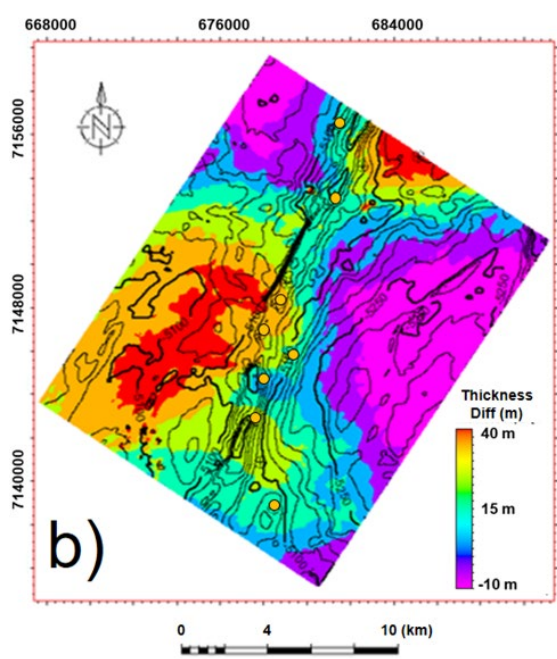

Diff: Cycles Inversion - Standard Inversion

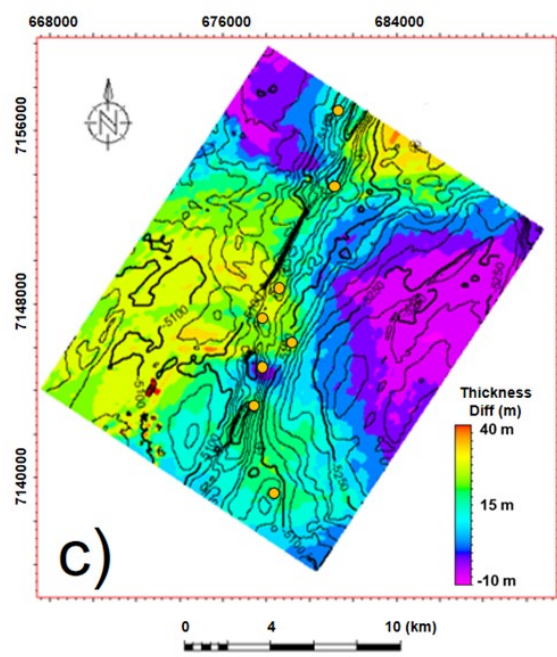

Figure 10 - GRV difference maps comparing the Salt Cycles Seismic Inversion Model and the other models. a) GRV difference between Salt Cycles Seismic Inversion Model and Constant Velocity Model; b) GRV difference between Salt Cycles Seismic Inversion Model and Tomographic Model; and c) GRV difference between Salt Cycles Seismic Inversion Model and Standard Seismic Inversion Model. Note the largest GRV variation to SW, due to the difficulty of the models to represent correctly the geologically complex areas (e.g., the salt heterogeneity).

SW portion of the study area, where a thicker halite over a stratified salt layer occurs, suggesting that this is not captured by the inversion tomography updating algorithms during the seismic processing phase. This is in accordance with the conclusions presented by Pontes et al. (2019).

\section{CONCLUSION}

Our results confirm that the salt section in the Santos Basin is not a homogeneous section presenting heterogeneities that result from the salt evaporative cycles. Non-homogeneous, stratified salt bodies usually are not solved due to the intrinsic absence of seismic resolution.

The incorporation of stratification, with appropriate velocities for different stratified lithologies when building velocity models, using seismic inversion, especially including the seismic tractable units, brings strong improvements to depth positioning, by reducing the mismatch between reference well markers and seismic events.

Different salt velocity models provide different Gross Rock Volumes (GRV) for the pre-salt reservoir. In the present study, the Salt Cycles Seismic Inversion Model resulted in the smallest average mismatch in relation to the well-marker information. We proved that the industry standard Inversion Tomographic Model approach gives a GRV 6\% higher than the Salt Cycles Seismic Inversion Model, which is a relevant volumetric difference impacting the whole production concept of a hydrocarbon field.

\section{ACKNOWLEDGEMENTS}

The authors would like to thank the ANP for the authorization to use the data necessary for the development of this project, and for allowing the publication of the obtained results. The authors also would like to thank Petrobras for all the financial support and availability of time and equipment for this study, as well as the colleagues who have been collaborating with this research.

\section{REFERENCES}

AMARAL PJ, MAUL A, FALCÃO L, GONZÁLEZ M, GONZÁLEZ G. 2015. Estudo estatístico da 
velocidade dos sais na camada evaporítica na Bacia de Santos. In: $14^{\text {th }}$ International Congress of the Brazilian Geophysical Society, Rio de Janeiro, RJ, Brazil. doi: 10.1190/sbgf2015-131.

CARMINATTI M, WOLFF B, GAMBOA L. 2008. New exploratory frontiers in Brazil. In: 19 ${ }^{\text {th }}$ World Petroleum Congress. Madrid, Spain. Paper WPC-19-2802.

FIDUK JC, ROWAN MG 2012. Analysis of folding and deformation within layered evaporites in Blocks BM-S-8 \& -9, Santos Basin, Brazil In: Salt Tectonics, Sediments and Prospectivity, Geological Society of London Special Publications, vol. 363 (2012), p. 471487.

FONSECA J, GOBATTO F, BOECHAT J, MAUL A, YAMAMOTO T, BORN E, TEIXEIRA L, GONZÁLEZ M. 2017. Dealing with Evaporitic Salts Section in Santos Basin during Geological Seismic Velocity Construction. In: $5^{\text {th }}$ International Congress of the Brazilian Geophysical Society. Rio de Janeiro, RJ, Brazil. doi: 10.1190/sbgf2017-350.

FONSECA J, TEIXEIRA L, MAUL A, BARROS P, BOECHAT J, GONZÁLEZ M. 2018. Modelling Geological Layers into new Velocity Models for Seismic Migration Process: A Brazilian pre-salt Case. In: First EAGE/PESGB Workshop on Velocities. London, United Kingdom. doi: 10.3997/2214-4609.201800010.

FREITAS JTR. 2006. Ciclos Deposicionais Evaporíticos da Bacia de Santos: Uma Análise Cicloestratigráfica a partir de Dados de 2 Poços e de Traços de Sísmica. Master's Dissertation. UFRGS. Porto Alegre, RS, Brazil. 160 pp.

GAMBOA LAP, MACHADO MAP, SILVEIRA DP, FREITAS JTR, SILVA SRP. 2008. Evaporitos estratificados no Atlântico Sul: Interpretação Sísmica e Controle Tectono-Estratigráfico na Bacia de Santos. In Sal: Geologia e Tectônica. Beca Edições Ltda. São Paulo - SP - Brazil. p. 340-359.

GOBATTO F, MAUL A, FALCÃO L, TEIXEIRA L, BOECHAT JB, GONZÁLEZ M, GONZÁLEZ G. 2016. Refining Velocity Model within the Salt Section in Santos Basin: an Innovative Workflow to include the Existing Stratification and its Considerations. (Society of Exploration Geophysicist - 2016) Dallas, TX. doi: 10.1190/segam2016-13685489.1.

HUANG Y, LIN D, BAI B, ROBY S, RICARDEZ C. 2010. Challenges in Pre-Salt Depth Imaging of the
Deepwater Santos Basin, Brazil. The Leading Edge, 29(7): 820-825. doi: 10.1190/1.3462785.

JACKSON C, JACKSON $M$, HUDEC $M$, RODRIGUEZ C. 2014. Internal structure, kinematics, and growth of a salt wall: Insights from 3-D seismic data. Geology. 42. 307-310. doi: 10.1130/G34865.1.

JACKSON CAL, JACKSON MPA, HUDEC MR, RODRIGUEZ CR. 2015. Enigmatic structures within salt walls of the Santos Basin-Part 1: Geometry and kinematics from 3D seismic reflection and well data: Journal of Structural Geology, v. 75, p. 135-162, https:// doi.org/10.1016 /j. jsg2015.01.010.

JI S, HUANG T, FU K, LI Z. 2011. Dirty Salt Velocity Inversion: The Road to a Clearer Subsalt Image. Geophysics, 76(5): WB169-W174. doi: 10.1190/GEO2010-0392.1.

KUKLA PA, MOHRIAK, WU, STROZYK F. 2017. South Atlantic salt basins - Witnesses of complex passive margin evolution. Gondwana Research (2018) (p. 41-57). doi: 10.1016/j.gr.2017.03.012.

MANN J, RIGG J. 2012. New geological insights into the Santos Basin. GEOExPro, 9, 36-40.

MAUL A. 2020. Caracterização Sísmica da Seção Evaporítica Salina E Suas Aplicações nos Projetos de Exploração, Desenvolvimento $E$ Produção de Hidrocarbonetos. Doctor's Thesis. UFF. Dinâmica Oceânica e Costeira. Niterói, RJ, Brazil. 263 pp.

MAUL A, CETALE M, GUIZAN C, CORBETT P, UNDERHILL J, TEIXEIRA L, PONTES R, GONZÁLEZ M. 2021. The impact of heterogeneous salt velocity models on the gross rock volume estimation: an example from the Santos Basin presalt, Brazil. Petroleum Geoscience 27(4): 1-17. https://doi.org/10.1144/petgeo2020-105.

MAUL A, JARDIM F, FALCÃO L, GONZÁLEZ G. 2015. Observing Amplitude Uncertainties for a PreSalt Reservoir Using Illumination Study (Hit-Maps). In: $77^{\text {th }}$ EAGE Conference \& Exhibition. Madrid, Spain. doi: 10.3997/2214-4609.201412921.

MAUL A, FONSECA J, TEIXEIRA L, BARROS P, BOECHAT JB, NUNES JP, YAMAMOTO T, GONZÁLEZ M, GONZÁLEZ G. 2018a. Modelling Intra-Salt Layers when Building Velocity Models for Depth Migration. Examples of the Santos Basins, Brazilian Offshore. In: $88^{\text {th }}$ Annual Meeting. SEG Society of Exploration Geophysicist. Anaheim, CA, USA. doi: 10.1190/segam2018-2996209.1. 
MAUL A, SANTOS MAC, SILVA CG. 2018b. Evaporitic Section Characterization and its Impact over the pre-salt Reservoirs, Examples in Santos Basin, Offshore. In: Rio Oil\&Gas Expo \& Conference 2018. Rio de Janeiro, RJ, Brazil. IBP.

MAUL AR, SANTOS MAC, SILVA CG. 2018c. Few Considerations, Warnings and Benefits for the E\&P Industry when Incorporating Stratifications inside Salt Sections. Brazilian Journal of Geophysics, 36(4): 461-477. doi: 10.22564/rbgf. v36i4.1981.

MAUL AR, SANTOS MAC, SILVA CG, FONSECA JS, GONZÁLEZ MLAF, TEIXEIRA LMS, YAMAMOTO TM, BORGES FAS, PONTES RLB. 2019. Geological Characterization of Evaporitic Sections and its Impacts on Seismic Images: Santos Basin, Offshore Brazil. Brazilian Journal of Geophysics, 37(1): 55-68. doi: 10.22564/rbgf. v37i1.1989.

MENEGUIM TB, MENDES SC, MAUL AR, FALCÃO LF, GONZÁLEZ MLAF, GONZÁLEZ G. 2015. Combining seismic facies analysis and well Information to guide new interval velocity models for a Pre-Salt study, Santos Basin, Brazil. In: 14 International Congress of the Brazilian Geophysical Society. Rio de Janeiro, RJ, Brazil. doi: 10.1190/sbgf2015-271.

MOHRIAK W, SZATMARI P, ANJOS SMC (Eds.). 2009. Sal: Geologia e Tectônica. Beca Edições Ltda. São Saulo, SP, Brazil. 448 pp.

MOHRIAK WU, SZATMARI P, ANJOS S. 2012. Salt: geology and tectonics of selected Brazilian basins in their global context. Geological Society, London, Special Publications, 363, 131-158, https://doi.org/10.1144/SP363.7.

MONTARON B, TAPPONNIER P. 2010. A quantitative model for salt deposition in actively spreading basins: American Association of Petroleum Geologists Search and Discovery Article 30117.

MOREIRA JLP, MADEIRA C, GIL JA, ACHADO MAP. 2007. Bacia de Santos. Boletim Geociências Petrobras, 15: 531-549.

PONTES RLB. 2019. Seismic Characterization of Internal Salt Cycles: A Case Study in Santos Basin, Brazil. Master's Dissertation. UFF. Dinâmica Oceânica e Costeira. Niterói, RJ, Brazil. 36 pp.
PONTES R, MAUL A, GUIZAN C. 2018. Considerações sobre os Ciclos Evaporíticos da Bacia de Santos. In: Congresso Brasileiro de Geologia. Rio de Janeiro, RJ, Brazil. doi: 10.13140/RG.2.2.10616.29443.

PONTES R, MAUL A, GUIZAN C. 2019. Interpretation, Characterization and Importance of the Internal Salt Cycles for Seismic Processes: a Santos Basin Example. In: 16 $6^{\text {th }}$ International Congress of the Brazilian Geophysical Society. Rio de Janeiro, RJ, Brazil. doi: 10.22564/16cisbgf2019.193.

QUIRK DG, SCHØDT N, LASSEN B, INGS SJ, HSU D, HIRSCH KK, VON NICOLAI C. 2012. Salt tectonics on passive margins: examples from Santos, Campos and Kwanza basins. Geological Society, London, Special Publications, 363: 207244, https://doi.org/10.1144/SP363.10.

RODRIGUEZ CR, JACKSON CAL, ROTE-VATN A, BELL RE, FRANCIS M. 2018. Dual tectonic-climatic controls on salt giant deposition in the Santos Basin, offshore Brazil. Geosphere, 14(1): 215-242. doi: 10.1130/GES01434.1.

TARANTOLA A. 1984. Inversion of Seismic Reflection Data in the Acoustic Approximation. Geophysics, 49: 259-1266. doi: 10.1190/1.1441754.

TEIXEIRA L, LUPINACCI W, MAUL A. 2020. Quantitative and stratigraphic seismic interpretation of the evaporite sequence in the Santos Basin. Marine and Petroleum Geology, 122, 1-17, https://doi.org/10.1016/j.marpetgeo.2020.104690.

USIGLIO J. 1849, Analyse de l'eau de la Mediterranee sur les cotes de France: Annalender Chemie, v. 27, p. 92-107, 172-191.

WARREN J. 2006. Evaporites: Sediments, Resources and Hydrocarbons. Springer. 1035 pp.

WARREN J. 2016. Evaporites - A Geological Compendium. 2nd ed. Springer. 1822 pp.

YILMAZ Ö. 2001. Seismic data analysis: Processing, inversion, and interpretation of seismic data. Society of Exploration Geophysicists. 2027 pp. doi: 10.4043/22827-MS.

ZHANG Y, WANG D. 2009. Traveltime InformationBased Wave-Equation Inversion. Geophysics, 74(6): CC27-WCC36. doi: 10.1190/1.3243073. 
R.P.: conceptualization (lead), formal analysis (lead), investigation (lead), methodology (lead), project administration (lead), software (lead), validation (lead), writing - original draft (lead); A.M.: conceptualization (equal), formal analysis (supporting), investigation (supporting), methodology (equal), project administration (supporting), software (supporting), validation (equal), writing - original draft (equal); C.G.: conceptualization (equal), formal analysis (supporting), investigation (supporting), methodology (equal), project administration (supporting), software (supporting), validation (supporting), writing - original draft (supporting).

Received on March 24, 2021 / Accepted on June 2, 2021

Recebido em 24 de março de 2021 / Aceito em 2 de junho de 2021 